
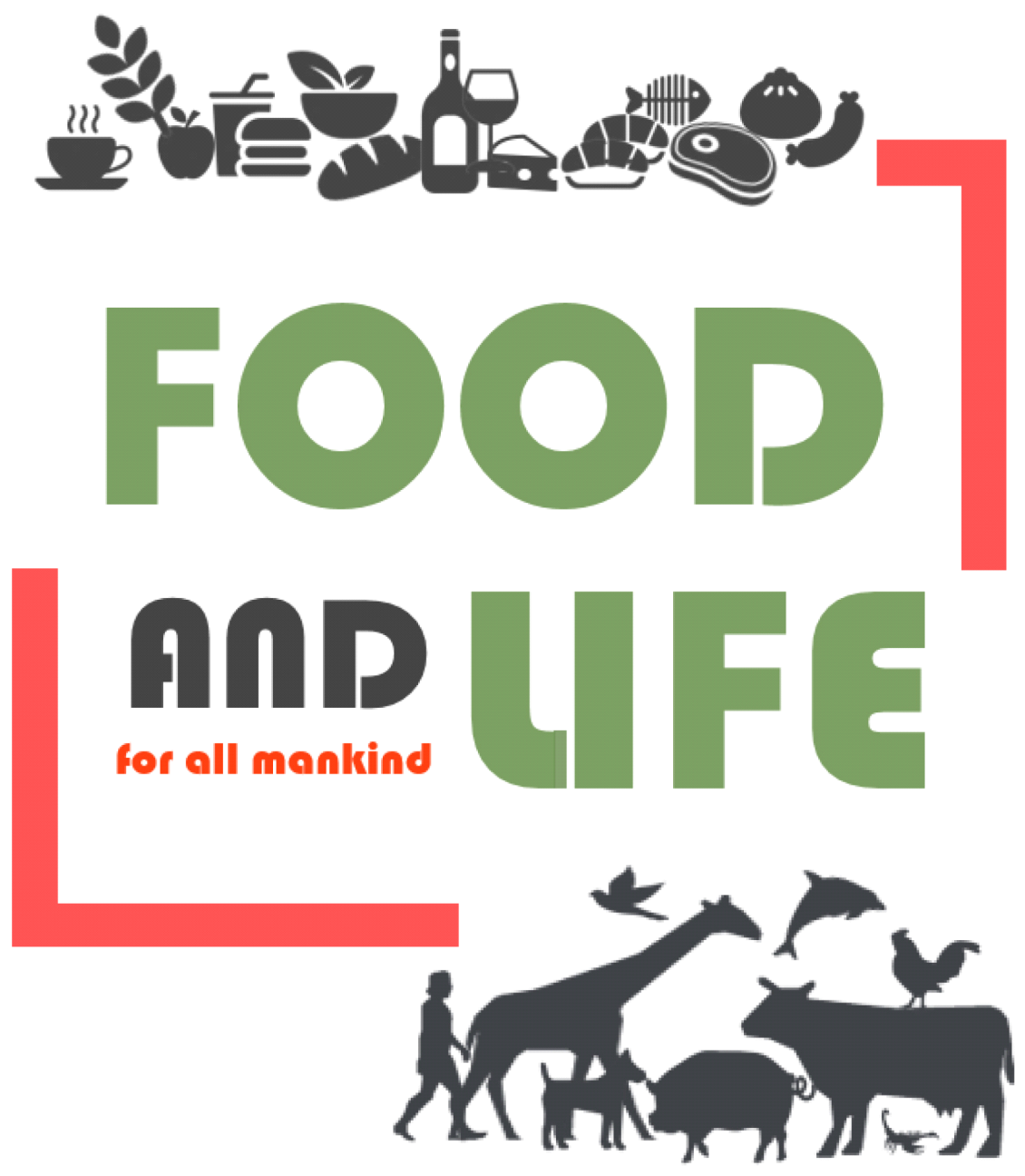

The Food and Life has published all type articles such as research articles, review articles, survey articles, research note, short communication or editorial since 2020. It covers the all scientific and technological aspects of food and life science.

\title{
https://www.foodnlife.org
}




\title{
클린라벨 육제품의 기술 전략
}

용해인 ${ }^{1}$, 김태경 ${ }^{1}$, 최희돈 ${ }^{1}$, 정사무엘 $^{2}$, 최윤상 ${ }^{1 *}$

1한국식품연구원 가공공정연구단

2충남대학교 동물자원과학부

\section{Technological Strategy of Clean Label Meat Products}

\author{
Hae In Yong ${ }^{1}$, Tae-Kyung Kim¹, Hee-Don Choi ${ }^{1}$, Samooel Jung ${ }^{2}$, Yun-Sang Choi ${ }^{1, *}$ \\ ${ }^{1}$ Researcher Group of Food Processing, Korea Food Research Institute, Wanju 55365, Korea \\ ${ }^{2}$ Division of Animal and Dairy Science, Chungnam National University, Daejeon 34134, Korea
}

\begin{abstract}
The income raise induces the change of the consumer perception about food. Chemical synthesis ingredients for food have been denied by consumer and interest about clean label food has been increased. When manufactured meat products, various ingredients are added to enhance quality properties of meat products. It is typical ingredients that color coupler, acidity control agent, preservatives, antioxidant, coloring agent, flavor enhancer, spice, and sweetener for meat products. Some ingredients such as nitrite, phosphate, sorbate were regulated and limited for using because of their negative effects on health. With this concern about aforementioned ingredients, various studies and effort to replace or reduce these ingredients have been conducted using natural ingredients in academy, institute, and industry. However, there were no specific definition about 'clean label' and consumer have bought clean label foods without clear information and comprehension. Therefore, regulation and definition for clean label foods have to be conducted.
\end{abstract}

Keywords: clean label, meat product, natural, ingredient, nitrite, phosphate

서 론

소득수준이 증가함에 따라 소비자들은 식품의 양보다는 질 적인 품질을 중시하게 되었고, 이는 다양한 기능성 식품 소재 를 활용한 신제품 개발이 증가하게 되었다. 또한 새로운 기능성 소재 개발뿐만 아니라, 화학적 합성 첨가물에 대한 거부감도 상 당히 증가하게 되었다(Ryu and Lee, 2018). 이러한 추세로 인해 화학적 첨가물을 활용한 제품보다는 자연 친화적인 천연 첨가물 을 활용한 제품들이 각광을 받게 되었다(Kim et al., 2017).

클린라벨(clean label)은 식품에 부여하는 라벨로서 1990년 대 영국에서 시작되었으며, 합성첨가물 무첨가, 가공 최소화, 간결한 원료 리스트, 이해가 쉬운 원료 선택, 전통 가공방법 사 용 등을 필수요건으로 하고 있다(Lee, 2015). 클린라벨 식품은 제품 내 함유 성분을 소비자들에게 명확하고, 이해하기 쉽게 표 기하였다는 점에서 소비자들에게 각광받고 있다(Asioli et al., 2017). 특히 식품첨가물이 많이 포함되고 제조방법이 복잡한 식 육제품에서의 클린라벨은 중요한 관심사항 중에 하나이다.
식육가공 산업은 수십 년간 비약적으로 발전하였으나, 소비 자들의 건강에 대한 이슈들로 인하여 위기에 직면해 있다. 특히 2015년 세계보건기구(WHO) 산하 국제암연구소(International Agency for Research on Cancer, IARC)에서 '식육가공식품 및 적색육의 발암성'에 대한 발표 이후, 식육가공품의 소비가 급 감하여 가공육 매출이 전년도 동기 대비하여 $40 \%$ 이상 감소하여 식육가공산업 발전을 저해하였다(Hur et al., 2015; Opinionnews, 2015). 특히 식육가공품에 첨가되는 아질산염이나 인산염과 같 은 합성첨가물에 대한 위해성과 관련이 있으며, 이는 식품첨가 물을 천연소재로 대체하거나 배제하여 건강에 해롭지 않은 식 육가공품 개발에 중점이 있다(Kim et al., 2019). ‘친환경', ‘유 기농', ‘자연주의', ‘합성첨가물 무첨가'와 같은 키워드는 이제 식육가공 산업에서 일반적인 용어가 되었으며, 이는 클린라벨 과도 관련이 있다(Câmara et al., 2020).

식육가공품 소비량이 증가함에 따라 식품첨가물 섭취량도 동반 증가하고 있다. 특히 식품첨가물은 식육가공품에 광범위

\footnotetext{
"Corresponding author : Yun-Sang Choi. Researcher Group of Food Processing, Korea Food Research Institute, Wanju 55365, Korea. Tel: +82-63-219-9387, Fax: +82-63-219-9076, E-mail: kcys0517@kfri.re.kr
}

This is an Open-Access article distributed under the terms of the Creative Commons Attribution Non-Commercial License which permits unrestricted non-commercial use, distribution, and reproduction in any medium, provided the original work is properly cited (http://creativecommons.org/licenses/by-nc/4.0/). 
하게 사용되고 있어서 독성평가를 통해 인체노출안전기준을 설정하여 관리하고 있다(Gassara et al., 2016). 또한 일부 식육 가공품에 첨가되는 첨가물에 위해성 제기가 식품첨가물 전체 에 대한 소비자 불안 심리를 자극하여 관련 업계는 대체기술 개발 등 다양한 해결 방안을 모색하고 있다.

따라서 본 연구에서는 식품 중에서 첨가물이 많이 포함되는 식육가공품에서 클린라벨 관점의 식육가공 기술에 대한 정보 와 활용 방법에 대하여 중점적으로 논의하고자 한다.

\section{식육가공품의 현황}

식품공전에서 식육가공품은 식육 또는 식육가공품을 주원료 로 하여 가공한 햄류, 소시지류, 베이컨류, 건조저장육류, 양념 육류, 식육추출가공품, 식육함유가공품 등이 있다(Korean Food Standards Codex, 2020). 햄류에는 햄, 생햄 및 프레스햄으로 나누어지며, 소시지류는 소시지, 발효소시지 및 혼합소시지로 구분된다. 이러한 식육가공품은 식육을 원료로 하여 식품첨가 물을 가한 후 정형, 염지, 숙성, 건조, 훈연, 가열 등의 가공공정 을 통하여 제조되는 것이 일반적이다. 생햄 및 발효소시지의 경우는 미생물을 활용한 발효 및 숙성 공정이 포함되어 있는 것이 특징이다. 식육가공품은 다양한 식품첨가물을 활용하고 있어서 식품 규격으로 아질산 이온, 타르 색소, 보존료(소브산, 소브산칼륨, 소브산칼슘)에 대한 기준이 제시되어 있다. 2019 년 국내 식육가공품 판매량은 21만 3천 20톤으로 세부적으로 6만 993톤, 소시지 8만 342톤, 베이컨 1만 1천 315톤, 캔햄 5만 7천 370톤 등이 판매되었다. 국내 식육가공품 시장은 매년 성 장세를 이어오고 있으며, 식품시장에서 가장 중요한 자리를 차 지하고 있다(Korea Meat Industries Association, 2020).

그러나 건강지향으로서 식품의 소비 패턴 변화는 소금, 합성 식품첨가물 등이 포함되어 있는 식육가공품의 소비 증대에 제 약으로 작용할 수 있다. 합성 식품첨가물이나 지방 및 소금 함 량을 조절하는 식육가공기술을 개발하고 있지만, 식육가공품 시장에서 차지하는 비중은 제한적이다. 또한 국내의 식육 단백 질의 섭취 문화는 단순 구워 먹는 식습관이 대부분으로, 인기 부위인 삼겹살은 공급이 부족하나, 다른 부위들은 비인기 부위 로 재고 관리의 어려움이 있다. 이러한 부위별 수급 불균형을 해결할 수 있는 방안으로써 비인기 부위를 활용한 다양한 식육 가공품의 소비 확대가 절실하다. 그러므로 건강 중시 경향에 따라 저지방, 저염, 무첨가 등의 식육가공품 판매는 앞으로도 증가할 것이며, 국내산 식육에 대한 신뢰가 높아 국내산 식육 함량이 높은 식육가공품 판매도 증가할 것으로 예상된다.

\section{식육가공품의 식품첨가물}

식품첨가물은 식육가공품에 폭넓게 사용되고 있고, 독성 평 가를 통해 인체노출안전기준을 설정하여 첨가량이 엄격하게
규제되며 관리되고 있다. 식육가공품에 주로 첨가되는 것을 사 용목적에 따라 분류하였을 경우, 발색제, 보존료, 산화방지제, 착색료, 향미증진제, 향료, 산도조절제, 감미료 등으로 나뉠 수 있다(Kim et al., 2017). 사용목적에 따른 식품첨가물의 분류는 Table 1에 나타내었다. 대표적인 발색제로 사용되는 것은 아질 산염이 있다. 아질산염은 주로 발색, 항산화, 풍미 증진 등의 역 할을 하고 있으며, Clostridium botulinum의 생장 및 독소 생성을 억제시키는 역할을 한다(Honikel, 2008). 그러나 식품 및 생체내 의 잔존 아질산염은 그 자체가 독성을 가지며, 다량 섭취할 경우 혈액의 hemoglobin을 methemoglobin으로 산화시켜 methemoglobin증을 일으키며, 제 2 급 및 제 3 급 아민류와 반응하여 발 암성 nitrosamine을 생성하기도 하는 것으로 보고되었다(Smith, 1967). 1961년 FAO/WHO 합동 식품첨가물 전문가회의(Joint FAO/WHO Expert Committee on Food Additives, JECFA)는 아 질산 이온의 독성 평가를 수행하였으며, 2003년 이후 일일허용섭 취량을 $0-0.07 \mathrm{mg} / \mathrm{kg} / \mathrm{day}$ 를 권고하였다. 유럽식품안전청(European Food Safety Authority, EFSA)은 1992년 아질산 이온의 독성 평 가를 수행하였으며, JECFA의 평가결과를 준용하여 2008년 일 일허용섭취량을 $0.07 \mathrm{mg} / \mathrm{kg}$ /day로 권고하였다. 이와 같이 독성 평가의 수행 및 일일허용섭취량의 권고와 더불어 세계보건기 구산하의 국제암연구소(IARC)는 아질산이온이 첨가되는 적색 육과 육가공품의 소비와 발암성의 관련을 평가한 연구결과를 발표하였다. 이에 따라 식육가공품이 1 급 발암물질로 분류되었 으며, 매일 약 $50 \mathrm{~g}$ 이상 식육가공품을 섭취할 경우, 대장암이 나 직장암 발병률이 $18 \%$ 정도 증가할 수 있다고 보고하였다. 식육의 경우, 매일 $100 \mathrm{~g}$ 씩 소비할 경우 대장암 발병률이 $17 \%$ 정도 증가한다고 보고하여 2급 발암물질로 분류되어 식육가공 품에 대한 소비자 불안심리를 증대시켜 소비를 위축시키고 있 다. 그러나 식육가공품에 의해 발병되는 대장암의 비율을 \%로 비교하였을 경우 $0.008 \%$ 증가하여 매우 적은 비율이 증가하였 다(Bouvard et al., 2015). 위에서 언급한 아질산염의 건강 위험 성 때문에 육가공품 또는 식육에 대한 소비자 선호도는 감소하 였으며, 연구자들은 아질산염을 대체할 수 있는 방안에 대하여 연구하고 있다. 대표적인 방법으로는 식물의 포함되어 있는 질 산염을 환원시켜 아질산염으로 사용하는 것이며, 다른 방안으 로는 착색제, 항산화제, 항미생물 물질 등의 복합적인 사용이 있다(Eskandari et al., 2013; Gassara et al., 2016). 식육가공품 에 첨가되는 아질산염 외에도 다양한 합성첨가물들에 대한 대 체 방안들이 연구되어오고 있다. 인산염의 경우, $\mathrm{pH}$ 를 조절하 여 식육가공품의 보수성, 항산화성, 미생물적 안정성 등에 있어 중요한 역할을 하고 있다(Long et al., 2011; O'Flynn et al., 2014). 그러나 과도한 인산염의 섭취는 신부전증 등의 신장질 환의 원인이 될 수 있으며, 칼슘이온섭취 없이 인산염을 과다 섭취할 경우 부갑상선 호르몬 수치를 증가시키고, 골밀도를 감 
Table 1. Classification of food additives for meat products by purpose of use

\begin{tabular}{|c|c|c|}
\hline Purpose category & Function & Additives name \\
\hline Color coupler & $\begin{array}{l}\text { There is no color in itself, so there is no effect of } \\
\text { coloring, but it combines with colored substances } \\
\text { present in meat and stabilizes the intrinsic pigment to } \\
\text { make it clear. }\end{array}$ & $\begin{array}{l}\text { - Sodium nitrite } \\
\cdot \text { Sodium nitrate }\end{array}$ \\
\hline Acidity control agent & $\begin{array}{l}\text { It has the effect of improving water retention and } \\
\text { binding capacity by adjusting the } \mathrm{pH} \text { of processed meat } \\
\text { products, and plays an important role in enhancing the } \\
\text { antioxidant effect and reducing cooking loss. }\end{array}$ & - Phosphate types \\
\hline Preservatives & $\begin{array}{l}\text { Mainly serves to prevent food spoilage and rancidity by } \\
\text { inhibiting microbial growth of processed meat products. }\end{array}$ & $\begin{array}{l}\text { - Smoking-derived ingredients } \\
\cdot \text { Sorbic acid } \\
\cdot \text { Potassium sorbate }\end{array}$ \\
\hline Antioxidant & $\begin{array}{l}\text { It has antioxidant effects such as preventing the } \\
\text { oxidation of lipids by oxygen in the air, thereby } \\
\text { inhibiting the formation of lipid rancidities in meat } \\
\text { products such as peroxides or aldehydes. }\end{array}$ & $\begin{array}{l}\cdot \text { Ascorbic acid } \\
\cdot \text { Sodium ascorbate } \\
\text { - Sodium erythorbate }\end{array}$ \\
\hline Coloring agent & $\begin{array}{l}\text { Due to the addition of fat, starch, and soy protein when } \\
\text { manufacturing processed meat products, it is difficult to } \\
\text { obtain the color desired by consumers with only color } \\
\text { coupler and it is difficult to obtain uniform colors. }\end{array}$ & $\begin{array}{l}\cdot \text { Cochineal } \\
\cdot \text { Lac dye } \\
\cdot \text { Red color agent }\end{array}$ \\
\hline Flavor enhancer, spice and sweetener & Food additives to enhance flavor of meat products. & $\begin{array}{l}\text { Flavor enhancer: L-monosodium } \\
\text { glutamate, Disodium 5'-inosinate, } \\
\text { Sodium guanylate, Sodium } \\
5 \text { '-ribonucleotide } \\
\text { - Natural spices } \\
\text { - Sweetner: Glucose, Lactose, Sodium } \\
\text { saccharin }\end{array}$ \\
\hline
\end{tabular}

소시킬 수 있다고 보고되었다(Long et al., 2011). JECFA는 인 산염의 일일섭취허용량(acceptable daily intake, $\mathrm{ADI}$ )를 70 $\mathrm{mg} / \mathrm{kg} / \mathrm{day}$ 로 제한하여 섭취하라고 규제하고 있다. 이에 따라 인산염 대체를 하기 위한 연구도 진행되어오고 있으며, 대표적 으로 초고압 또는 보수성을 증가시킬 수 있는 천연물의 첨가를 통해 진행되고 있다(Desmond, 2006). 합성보존료로 사용되고 있는 소르빈산칼륨(potassium sorbate)과 소르빈산(sorbic acid) 등은 신장관련 질환, 알레르기 반응 등을 일으키는 동시에, 아 질산 나트륨 또는 아초산 나트륨과 함께 첨가될 경우 세포의 돌연변이 생성률을 증가시킬 수 있다고 보고되었다(Stopforth et al., 2005). 대부분의 사람들에겐 이러한 부작용을 나타내지 않아 generally recognized as safe(GRAS)로 인정받고 있으나, JECFA에 의해 0-2.5 mg/kg/day로 규제되고 있다. 국내 식육가 공품에 첨가되는 식품첨가물의 규격은 일반적으로 아질산 이 온이 $0.07 \mathrm{~g} / \mathrm{kg}$ 미만, 타르색소는 검출되어선 안 되며, 보존료 의 경우 소브산, 소브산칼륨, 소브산칼슘을 제외한 보존료가 검 출되어서는 안 되며, 소브산으로서 약 $2.0 \mathrm{~g} / \mathrm{kg}$ 으로 제한되어 있다(식품의약품안전처, 2020).

\section{클린라벨 식육가공 기술 동향}

클린라벨은 합성첨가물이 들어가지 않고 최소한의 가공으로 생산된 식품에 부여되는 것으로서 새로운 식품의 기준으로 부 상하고 있다(Ryu and Lee, 2018). 식품이 어떠한 원료를 사용 하는 지에 대한 소비자의 관심이 높아짐에 따라, 식육가공산업 또한 합성첨가물 대체 가공기술을 확보하고, 클린라벨 제품을 생산하는데 큰 관심과 노력을 기울이는 실정이다(Moon, 2019).

\section{합성 아질산염 대체 기술}

식육가공품 내 첨가되는 합성 첨가제 중에서 소비자들이 가 장 불신하는 것은 바로 합성 아질산염이다. 특히, 2015년 이후 부터는 합성 아질산염의 위해성 논란이 극대화된 시기였으며, 이러한 소비자 불신의 가중은 합성 첨가제를 대체한 식육가공 제품에 대한 수요와 인기를 상승시켰다(Jeong, 2016).

식육가공품에서 합성 아질산염의 사용을 배제 또는 대체하 기 위한 방법은 크게 두 가지로 나눌 수 있다. 첫 번째는 직접 적인 대체방법으로서 제품 제조 시 질산염 및 아질산염의 사용 을 완전히 배제하고, 다른 천연 대체 소재를 첨가하는 개념이 
다. 하지만 아질산염은 염지 육색 발현, 항미생물 작용, 항산화 효과와 같은 복합적인 역할을 하고 있기 때문에 이러한 모든 기능을 대체할 수 있는 단독 첨가물을 찾는 것은 어려운 실정 이다(Kim et al., 2017). 먼저, 아질산염의 역할 중 하나인 염지 육색(붉은색) 발현을 위하여 가장 많이 사용되는 소재로는 토 마토 파우더, 홍국 등의 자색소를 포함하는 천연물이 있다 (Alahakoon et al., 2015). Savadkoohi 등(2014)는 토마토 퍼미 스 첨가량이 증가함에 따라 소고기 소시지의 적색도가 증가하 였으며, $3 \%$ 및 $5 \%$ 의 토마토 퍼미스 첨가는 소비자의 관능적 기 호도를 향상시킨다고 보고하였다. 치자(Gardenia jasminoides) 와 홍국(Monascus koji) 또한 특유의 붉은 수용성 색소를 가지 고 있어 아질산염의 발색효과를 대체하는데 사용이 가능하다 (Pak et al., 2020; Rhyu et al., 2003). Lee 등(2018)은 자색 색소 $0.2 \%$ 에 자색고구마 분말 $5 \%$ 를 추가하여 소시지의 적색을 향 상시키고, 아질산염 $0.15 \%$ 첨가군과 유사한 색을 나타냈다고 보고한 바 있다. 염지육색 발현 외에, 아질산염의 항균 및 항산 화 효과를 대체하고자 하는 연구들도 다양하게 수행되고 있다 (Jeong, 2016). 특히, 식품산업에서 다양하게 사용되고 있는 구 연산, 젖산, 소르비산 등의 유기산은 병원성미생물 및 부패미생 물의 세포막에 침투하여 adenosine triphosphate(ATP) 생성을 억 제하여 항균효과가 있다고 조사되었다(Alahakoon et al., 2015). 소시지에 젖산 나트륨 $3.3 \%$ 첨가 시 Listeria monocytogenes의 성장이 최소 2주까지 지연되었으며(Choi and Chin, 2003), 염 지된 돼지고기와 소고기에 구연산 나트륨 첨가 시 그 첨가량이 증가함에 따라 Clostridium perfringens spore의 발아와 성장이 지연되었다(Thippareddi et al., 2003). 이 외에도 폴리페놀 등의 다양한 항산화 성분들을 함유한 천연재료 사용 시 식육가공제품 의 산패를 제어하고, 저장기간을 연장시킬 수 있다(Alahakoon et al., 2015).

식육가공품에서 합성 아질산염의 사용을 대체하기 위한 두 번째 방법은 간접적인 사용 방법이다(Table 2). 아질산염의 모 든 역할을 대체할 수 있는 단독 첨가제를 찾는 것이 어렵기 때
문에, 합성 아질산염이 아닌 천연 아질산 공급원을 활용하는 것이 이에 해당한다(Kim et al., 2017). 채소류 중 샐러리, 시금 치, 비트, 무 등은 다량의 질산 이온 $\left(\mathrm{NO}_{3}\right)^{-}$을 함유하고 있으며, 이 를 아질산 이온 $\left(\mathrm{NO}_{2}{ }^{-}\right)$으로 환원시켜 식육가공품 제조 과정에 적 용할 수 있다. Kim 등(2019)은 시금치를 Staphylococcus carnosus 와 함께 24시간 배양하여 돼지고기 등심 햄에 사용할 경우, 붉 은색의 염지육색이 발현되며, 지방산패도가 제어되어 합성 아 질산염 대체제로서 사용 가능함을 제시하였다. 이러한 방법은 'Nature curing', ‘천연 아질산염' 등의 이름으로 국내·외 육제 품 생산에 적용되고 있는 대중화된 방식이다(Jeong, 2016). 1990 년대 해당 기술의 초기 개발단계에서는 육제품 내 아질산 이온을 함유한 채소 분말/채소즙을 육제품에 첨가한 후 질산 환원균과 함께 $38^{\circ} \mathrm{C}-42^{\circ} \mathrm{C}$ 에서 배양하여 제작했기 때문에 제조 시간이 길다는 단점이 있었다. 하지만, 최근 채소분말의 질산이 온을 종균과 함께 환원시킨 상태로 제조 및 상품화하여 제품 배양 시간을 단축시킬 수 있는 천연 소재들이 판매되고 있다 (Sebranek et al., 2012). 현재 천연 아질산염 첨가제로서 상업화 된 채소분말 제품의 질산이온 함량은 약 $30,000 \mathrm{ppm}$ 으로 보고 된다(Jeong, 2016). 국내에서는 CJ제일 제당, 롯데푸드, 목우촌, 청정원 등에서 위와 같은 방법을 활용하여 합성아질염 무첨가 식육가공품을 제조 및 판매하고 있다(Kim et al., 2017).

최근 합성아질산염을 대체할 수 있는 또다른 간접적인 방법 으로서 대기압 플라즈마 공정이 제시되고 있다. 플라즈마는 비 가열 살균공정 중 하나로서 reactive oxygen species와 reactive nitrogen species 등의 다양한 활성종들을 포함하여 박테리아, 바이러스, 곰팡이 등에 대한 살균효과가 있다. 이러한 플라즈마 기술은 환경 분야에서 폐수 살균과 정화에 이용되며 개발되어 오다가, 플라즈마가 처리된 물에 질산 이온과 아질산 이온이 생성됨이 밝혀지면서 다양한 육제품에 적용하는 연구들이 진 행되었다(Jung et al., 2017a). Yong 등(2018)은 플라즈마가 처 리된 물, 즉 플라즈마 처리수를 활용하여 돼지고기 등심 햄을 제작하였고, 합성 아질산염을 대체할 수 있음을 제시하였으며,

Table 2. Comparison of nitrite sources which can be used in meat products

\begin{tabular}{|c|c|c|c|c|}
\hline Curing methods & Nitrite sources & Reaction & Etc. & References \\
\hline $\begin{array}{l}\text { Synthetic nitrite } \\
\text { (Traditional method) }\end{array}$ & $\begin{array}{l}\text { - Sodium nitrite } \\
\text { - Potassium nitrite }\end{array}$ & Direct use of nitrite & - Commercialized & $\begin{array}{l}\text { Alahakoon et al., } 2015 \\
\text { Hu et al., } 2015\end{array}$ \\
\hline Natural nitrite & $\begin{array}{l}\cdot \text { Vegetable powder } \\
\cdot \text { Vegetable juice }\end{array}$ & $\begin{array}{l}\text { Nitrate contained in } \\
\text { vegetable is converted } \\
\text { into nitrite by reducing } \\
\text { bacteria }\end{array}$ & - Commercialized & $\begin{array}{l}\text { Hur et al., } 2015 \\
\text { Sebranek et al., } 2012\end{array}$ \\
\hline Plasma technology & $\begin{array}{l}\cdot \text { Plasma treated water } \\
\cdot \text { Direct plasma treatment } \\
\cdot \text { Plasma treated vegetable } \\
\text { source }\end{array}$ & $\begin{array}{l}\text { Generation of nitrite by } \\
\text { plasma discharge using } \\
\text { nitrogen and oxygen in } \\
\text { the atmospheric air }\end{array}$ & - Not commercialized & $\begin{array}{l}\text { Jung et al., } 2017 \mathrm{a} \\
\text { Jung et al., } 2017 \mathrm{~b} \\
\text { Yong et al., } 2018\end{array}$ \\
\hline
\end{tabular}


Kim 등(2016)은 플라즈마 처리수로 제작된 소시지가 유전독성 학적 및 면역학적으로 안전함을 보고하였다. 이후 플라즈마 처 리수를 활용하는 것이 아닌, 식육제품의 가공공정 중 플라즈마 를 직접 처리하여 유화형 소시지(Jung et al., 2017a) 및 돼지고 기 육포(Yong et al., 2019)를 제작한 바 있다. 또한, Jung 등 (2017b)은 질산이온은 없으나 항산화 등의 기능성 성분이 풍부 한 자소잎(Perilla frutescens)에 플라즈마를 처리하여 아질산이 온을 부과함에 따라, 새로운 천연 아질산염 대체 소재 생산 방 법을 제안하기도 하였다.

\section{인산염 대체 기술}

식육가공품에 첨가되는 인산염은 산도조절제로서, 보수력과 결착력의 증가, 조직감 개선의 목적으로 첨가하고 있다. 인산염 의 대체기술 연구는 육제품 내 $\mathrm{pH}$ 를 향상시키거나, 결착력을 증진시키는 소재 개발로 비육단백질(non-meat protein), 친수성 고분자 탄수화물, 칼슘염, 천연 첨가제, 그리고 단백질 효소 등 을 첨가하는 기술이 대부분을 차지하고 있다(Table 3).

비육단백질 소재로서는 분리대두단백질, 유청 단백질, 카제 인 등이 있으며, 친수성 hydrocolloid 계열의 고분자 탄수화물 소재로서는 구아검, L-아르기닌, 카라기난, 타피오카 전분 등이 있다(Kim et al., 2017). Kim 등(2014)은 L-아르기닌 첨가량이 증가함에 따라 소시지의 $\mathrm{pH}$ 가 유의적으로 증가하였으며, $0.5 \%$ $\mathrm{L}$-아르기닌 첨가군과 $0.5 \%$ 인산염 첨가군의 관능적 특성이 유 사하다고 보고하였다. Park 등(2008)에 의하면 구아검, 카라기 난, 알긴산의 첨가가 돈육혼합물의 보수력을 증가시켰으며, 이 중 카라기난과 구아검이 인산염과 유사한 가공특성과 유화안 전성을 나타냈다. 난각, 패류의 껍데기, 치즈 제조 시 분리되는
유청 등으로부터 얻을 수 있는 칼슘염은 산업 부산물로서 인산 염 대체제로 사용 시 경제성이 뛰어나다는 장점이 있다(Bae et al., 2017). Bae 등(2017)과 Cho 등(2017)은 위와 같은 다양한 칼슘염을 활용하여 돼지고기 분쇄 육제품 내 인산염을 대체할 수 있음을 제시하였다. 다양한 천염 첨가물을 또한 인산염 대 체제로서 사용이 가능하다. Choe 등(2018)에 따르면 팽이버섯 분말을 $0.5 \%$ 이상 첨가 시 육반죽의 $\mathrm{pH}$ 가 유의적으로 증가하 였으며, 제품화된 소시지의 지방산패도 값이 대조군보다 낮았 다. 또한, 팽이버섯이 $0.5 \%-1.5 \%$ 첨가된 소시지와 인산염 $0.3 \%$ 첨가된 소시지의 소비자 관능적 기호도에서 유의적인 차이가 나타나지 않았다. Lee 등(2018)은 유화형 소시지 제조 시 인산 염 대체제로서 다시다 분말을 사용할 수 있으며, 이는 다시다 분말 내에 함유된 L-아르기닌 등 때문이라고 보고하였다. 단백 질 간의 상호작용을 촉매하는 미생물 유래 효소(Microbial transglutaminase, MTGase) 역시 인산염 대체제로서 사용이 가 능하다. MTGase는 식육가공품 원료인 식육 단백질과 그물망 구조를 형성하여 결착력을 증진, 제품의 탄력성을 증가시킨다 (Santhi et al., 2017). 그러나 위와 같이 첨가제를 사용한 기술 들은 첨가량이 많아야 하므로 식육가공품의 관능적 특성이나 일부 품질적 요소들에 문제를 야기하는 것도 사실이다.

최근에는 식육가공제품 내 인산염 사용을 줄이거나 대체하 는 방안으로서 초고압기술(high-pressure)과 초음파 기술(ultra sound)를 활용하기도 한다. 식육단백질에 100-200 MPa 정도의 초고압 처리 시, 식육 내 염용성 단백질이 용출되어 식육제품 의 결착력 및 보수력이 증가할 수 있다. 염지육제품 제조 시 초 음파를 활용할 경우에는 염지제가 제품 내 빠르게 확산되어 염 지시간이 줄어들고, 결착력이 향상되어 인산염의 사용을 줄일

Table 3. Classification of phosphate replacement technologies

\begin{tabular}{|c|c|c|}
\hline Technologies & Ingredient examples / methods & References \\
\hline Non-meat protein & $\begin{array}{l}\cdot \text { Isolated soy protein } \\
\cdot \text { Whey protein } \\
\cdot \text { Casein protein }\end{array}$ & Kim et al., 2017 \\
\hline Hydrocolloid & $\begin{array}{l}\cdot \text { L-Arginine } \\
\text { - Carrageenan } \\
\text { - Gums (Gua gum, Xanthan gum, and etc.) }\end{array}$ & $\begin{array}{l}\text { Kim et al., } 2014 \\
\text { Part et al., } 2008\end{array}$ \\
\hline Calcium salts & - Calcium salts obtained from egg shell or oyster shell powder & $\begin{array}{l}\text { Bae et al., } 2017 \\
\text { Cho et al., } 2017\end{array}$ \\
\hline Enzyme & - Microbial transglutaminase & Santhi et al., 2017 \\
\hline Natural source & $\begin{array}{l}\text { - Winter mushroom powder } \\
\text { - Sea tangle powder }\end{array}$ & $\begin{array}{l}\text { Choe et al., } 2018 \\
\text { Lee et al., } 2018\end{array}$ \\
\hline High-pressure processing & - High pressure treatment for $100-200 \mathrm{MPa}$ & Thangavelu et al., 2019 \\
\hline Power ultrasound & $\begin{array}{l}\text { - Power ultrasound energy at frequencies higher than human audible } \\
\text { range }(>20 \mathrm{kHz}) \text { and lower than microwave frequencies }(10 \mathrm{MHz}) \text {. }\end{array}$ & Thangavelu et al., 2019 \\
\hline
\end{tabular}


수 있다(Thangavelu et al., 2019).

\section{합성 보존료 대체 및 안전성 증진 기술}

최근 다양한 안전성 향상 기술을 사용하여 식육가공제품의 관능 및 영양적 특성에 영향을 미치지 않으면서 제품의 유통기 한을 연장하는 기술들이 꾸준히 연구되고 있다. 이렇게 식품의 안전성을 연장할 수 있는 기술은 ‘최소 가공기술'이라고 칭하 며, 이 중 열의 사용 유무에 따라 '가열 가공기술'과 ‘비가열 가 공기술’로 나눌 수 있다(Kang, 2012).

식육가공식품의 안전성을 연장할 수 있는 여러 기술 중 가까 운 미래에 산업화 될 수 있는 기술들로는 초고압, 펄스 자기장, 자외선, 플라즈마, 마이크로파, 저항가열 등이 있다(Kim, 2018). 해당 기술들에 대한 자세한 정보는 Table 4 에 나타내었다.

\section{클린라벨 식육가공산업 전망}

식품첨가물은 '식품을 제조, 가공, 보존함에 있어 식품에 첨 가, 침윤, 기타의 방법으로 사용하는 것으로 사람의 건강을 해 할 우려가 없어야 하며, 이를 사용함으로써 소비자에게 이익을 주는 것'으로 국내 식품공전에 명시되어 있다. 이러한 식품첨 가물을 필요에 따라 정확히 사용한다면 크게 우려할 것은 아니 지만, 부적절한 사용 및 합성 첨가제에 대한 소비자의 불신이 더해감에 따라 클린라벨 제품들은 꾸준히 요구될 것이라 예측 된다(Moon, 2019). 미국, 영국 및 $\mathrm{EU}$ 을 포함한 전 세계적으로 클린라벨 시장은 크게 증가하고 있으며, 이는 식품산업에서 합 성 첨가물을 최소화 하고, 각종 표시제도를 재정비하도록 하고 있다. 하지만 현재, 클린라벨에 대한 명확한 기준이 없고, 나라 마다 상이한 제도를 가지고 있다는 큰 문제에 직면해 있다(Ryu and Lee, 2018). 특히, 샐러리 파우더 등의 천연 아질산 소재의 사용 시 이를 'nitrite-free' 또는 'Uncured' 제품으로 표기해도 되는지에 대한 의견은 여전히 분분한 상황이다(Sebranek et al., 2012). 소비자들 역시 클린라벨 식품에 대해 명확한 이해 없이

Table 4. Current technologies to control food-borne pathogens and spoilage bacteria

\begin{tabular}{lll}
\hline \multicolumn{1}{c}{ Technologies } & \multicolumn{1}{c}{ Name } & Reference \\
\hline $\begin{array}{l}\text { Thermal } \\
\text { sterilization }\end{array}$ & $\cdot$ Microwave-frequency & \\
technology & $\cdot$ Ohadio-frequency & Kang, 2012 \\
& $\cdot$ Infrared heating & \\
& $\cdot$ High-pressure processing & \\
Non-thermal & $\cdot$ Cold plasma & Kim, 2018 \\
sterilization & $\cdot$ Power ultrasound & \\
technology & $\cdot$ Pulsed electric field & \\
& $\cdot$ Ultraviolet light & \\
& $\cdot$ Radiation &
\end{tabular}

단순히 클린라벨의 이름이 전달하는 건강한 이미지 때문에 구 입한다는 분석도 있다(Ryu and Lee, 2018). 이러한 이유로 식 육가공산업은 단순히 클린라벨 관련 기술들을 확보할 뿐만 아 니라, 정부 및 기관들과 함께 국제적으로 통일된 규정들을 제 안하고 정립할 필요성이 있다.

\section{결 론}

식육가공품 제조 시 품질특성의 향상을 위해 다양한 첨가물 이 첨가되며, 대표적으로 발색제, 산도조절제, 보존료, 산화방 지제, 착색제, 풍미증강제, 향신료 및 감미료 등이 있다. 이 중 아질산염, 인산염, 소르빈산염과 같은 일부 첨가물은 사용에 규 제를 받고 있으며, 건강에 대한 부정적인 인식을 가지고 있다. 따라서 산업계에서는 부정적인 인식 개선을 위해 천연성분을 활용한 클린라벨 식육제품의 개발에 노력하고 있다. 그러나 클 린라벨 제품에 대한 명확한 정의는 존재하지 않아, 소비자는 단순히 제품의 이미지로만 구매를 하고 있는 실정이다. 따라서 정부 및 기관에서는 클린라벨 기술력 확보와 동시에 명확한 규 정을 제시할 필요가 있다.

\section{Conflicts of Interest}

The authors declare no potential conflict of interest.

\section{Acknowledgments}

This research was supported by Main Research Program (E0203239-01) of the Korea Food Research Institute (KFRI) funded by the Ministry of Science and ICT (Korea).

\section{Ethics Approval}

This article does not require IRB/IACUC approval because there are no human and animal participants

\section{Author Contributions}

Conceptualization: Choi YS

Data curation: Choi YS, Yong HI

Formal analysis: Yong HI, Kim TK, CHoi HD

Validation: Choi YS, Jung S, Yong HI

Investigation: Choi YS, Yong HI, Jung S

Writing-original draft: Choi YS, Yong HI, Kim TK

Writing-review\&editing: Choi YS, Yong HI, Kim TK

\section{Author Information}

Hae In Yong (Researcher, Korea Food Research Institute) https://orcid.org/0000-0003-0970-4496 
Tae-Kyung Kim (Researcher, Korea Food Research Institute) https://orcid.org/0000-0002-6349-4314

Hee-Don Choi (Senior Researcher, Korea Food Research Institute) https://orcid.org/0000-0001-8060-6237

Samooel Jung (Professor, Chungnam National University) https://orcid.org/0000-0002-8116-188X

Yun-Sang Choi (Research Scientist, Korea Food Research Institute) https://orcid.org/0000-0001-8060-6237

\section{References}

Alahakoon AU, Jayasena DD, Ramachandra S, Jo C. 2015. Alternatives to nitrite in processed meat: Up to date. Trends Food Sci Technol 45:37-49.

Asioli D, Aschemann-Witzel J, Caputo V, Vecchio R, Annunziata A, Næs T, Varela P. 2017. Making sense of the "clean label" trends: A review of consumer food choice behavior and discussion of industry implications. Food Res Int 99:58-71.

Bae SM, Cho MG, Jeong JY. 2017. Effects of various calcium powders as replacers for synthetic phosphate on the quality properties of ground pork meat products. Korean J Food Sci Anim Resour 37:456-463.

Bouvard V, Loomis D, Guyton KZ, Grosse Y, Ghissassi FE, Benbrahim-Tallaa L, Guha N, Mattock H, Straif K. 2015. Carcinogenicity of consumption of red and processed meat. Lancet Oncol 16:1599-1600.

Câmara AKFI, Vidal VAS, Santos M, Bernardinelli OD, Sabadini E, Pollonio MAR. 2020. Reducing phosphate in emulsified meat products by adding chia (Salvia hispanica L.) mucilage in powder or gel format: A clean label technological strategy. Meat Sci 163:108085.

Cho MG, Bae SM, Jeong JY. 2017. Egg shell and oyster shell powder as alternatives for synthetic phosphate: Effects on the quality of cooked ground pork products. Korean J Food Sci Anim Resour 37:571-578.

Choe J, Lee J, Jo K, Jo C, Song M, Jung S. 2018. Application of winter mushroom powder as an alternative to phosphates in emulsion-type sausages. Meat Sci 143:114-118.

Choi SH, Chin KB. 2003. Evaluation of sodium lactate as a replacement for conventional chemical preservatives in comminuted sausages inoculated with Listeria monocytogenes. Meat Sci 65:531-537.

Desmond E. 2006. Reducing salt: A challenge for the meat industry. Meat Sci 74:188-196.
Eskandari MH, Hosseinpour S, Mesbahi G, Shekarforoush S. 2013. New composite nitrite-free and low-nitrite meatcuring systems using natural colorants. Food Sci Nutr $1: 392-401$.

Gassara F, Kouassi AP, Brar SK, Belkacemi K. 2016. Green alternatives to nitrates and nitrites in meat-based productsa review. Crit Rev Food Sci Nutr 56:2133-2148.

Honikel KO. 2008. The use and control of nitrate and nitrite for the processing of meat products. Meat Sci 78:68-76.

Hur SJ, Jang A, Jeong JY, Jo C, Chin KB, Lee KT. 2015. Misunderstanding and truths for controversy of carcinogenic substances in meat products. Food Sci Anim Resour Ind 4:7-22.

Jeong JY. 2016. Alternative curing technology in meat products. Food Sci Anim Resour Ind 5:77-84.

Jung S, Lee CW, Lee J, Yong HI, Yum SJ, Jeong HG, Jo C. 2017a. Increase in nitrite content and functionality of ethanolic extracts of Perilla frutescens following treatment with atmospheric pressure plasma. Food Chem 237:191197.

Jung S, Lee J, Lim Y, Choe W, Yong HI, Jo C. 2017b. Direct infusion of nitrite into meat batter by atmospheric pressure plasma treatment. Innov Food Sci Emerg Technol 39: 113-118.

Kang DH. 2012. Current thermal/non-thermal technologies to control foodborne pathogens. Food Sci Ind 45:48-59.

Kim HJ, Sung NY, Yong HI, Kim H, Lim Y, Ko KH, Yun $\mathrm{CH}$, Jo C. 2016. Mutagenicity and immune toxicity of emulsion-type sausage cured with plasma-treated water. Korean J Food Sci Anim Resour 36:494-498.

Kim HS. 2018. Future technologies for the manufacture of safe meat products. Food Sci Anim Resour Ind 7:28-38.

Kim TK, Yong HI, Jang HW, Lee H, Kim YB, Jeon KH, Choi YS. 2019. Quality of sliced cured pork loin with spinach: Effect of incubation period with starter culture. J Food Qual 2019:6373671.

Kim TK, Ku SK, Kim YB, Jeon KH, Choi YS. 2017. Substitution and technology trend of synthetic additives in processed meat industry: Nitrite and phosphate. Food Sci Anim Resour Ind 6:98-108.

Kim YD, Lee JS, Park JH, Park DC, Jeon YS, In MJ, Oh NS. 2014. Application of 1 -arginine as a substitute for inorganic polyphosphate in pork sausage production. J Appl Biol Chem 57:171-174. 
Korean Food Standards Codex. 2020. Article 5. Food standards and codexs. 16. Processed meat products and packaged meat. Available from: https://www.foodsafetykorea.go.kr/ foodcode/01_03.jsp?idx=37. Accessed at Mar 12, 2020.

Lee H, Choe J, Yong HI, Lee HJ, Kim HJ, Jo C. 2018. Combination of sea tangle powder and high-pressure treatment as an alternative to phosphate in emulsion-type sausage. J Food Process Preserv 42:e13712.

Lee K. 2015. Industrialization trend of natural ingredient with clean label focusing on ingredion clean label products. Food Ind Nutr 20:11-14.

Long NHBS, Gál R, Buňka F. 2011. Use of phosphates in meat products. Afr J Biotechnol 10:19874-19882.

Moon S. 2019. Quality strategy for competitiveness of meat products. Food Sci Anim Resour Ind 8:2-11.

O'Flynn CC, Cruz-Romero MC, Troy D, Mullen AM, Kerry JP. 2014. The application of high-pressure treatment in the reduction of salt levels in reduced-phosphate breakfast sausages. Meat Sci 96:1266-1274.

Opinionnews, 2015. Consumers, ham and sausage processed meat exterior. Available from: http://www.opinionnews.co.kr/ news/ articleView.html?idxno=2904. Accessed at Mar 12, 2020.

Pak JI, Jung HS, Lee SK, Kim GY, Jhoo JW, Kang SM. 2020. Effect of substitution of nitrite with Gardenia jasminoides extract on quality characteristics of chicken meat patty. J Agric Life Environ Sci 32:34-43.

Park KS, Choi YI, Lee SH, Kim CH, Auh JH. 2008. Application of functional carbohydrates as a substitute for inorganic polyphosphate in pork meat processing. Korean J Food Sci Technol 40:118-121.

Rhyu MR, Kim EY, Chung KS. 2003. Effect of Monascus koji on the quality characteristics of bologna-type sausage. Korean J Food Sci Technol 35:229-234.

Ryu YA, Lee JS. 2018. Clean label guideline for entry into UK and EU agro-food markets. Food Ind Nutr 23:20-26.

Santhi D, Kalaikannan A, Malairaj P, Arun Prabhu S. 2017. Application of microbial transglutaminase in meat foods:
A review. Crit Rev Food Sci Nutr 57:2071-2076.

Savadkoohi S, Hoogenkamp H, Shamsi K, Farahnaky A. 2014. Color, sensory and textural attributes of beef frankfurter, beef ham and meat-free sausage containing tomato pomace. Meat Sci 97:410-418.

Sebranek JG, Jackson-Davis AL, Myers KL, Lavieri NA. 2012. Beyond celery and starter culture: Advances in natural/ organic curing processes in the united states. Meat Sci 92:267-273.

Smith RP. 1967. The nitrite methemoglobin complex-its significance in methemoglobin analyses and its possible role in methemoglobinemia. Biochem Pharmacol 16:16551664.

Stopforth JD, Sofos JN, Busta FF. 2005. Sorbic acid and sorbates. In Antimicrobials in food. $3^{\text {rd }}$ ed. Davidson PM, Sofos JN, Branen AL (ed). Taylor \& Francis, Boca Raton, FL, USA. pp 49-90.

Thangavelu KP, Kerry JP, Tiwari BK, McDonnell CK. 2019. Novel processing technologies and ingredient strategies for the reduction of phosphate additives in processed meat. Trends Food Sci Technol 94:43-53.

Thippareddi H, Juneja VK, Phebus RK, Marsden JL, Kastner CL. 2003. Control of Clostridium perfringens germination and outgrowth by buffered sodium citrate during chilling of roast beef and injected pork. J Food Prot 66:376-381.

Yong HI, Lee SH, Kim SY, Park S, Park J, Choe W, Jo C. 2019. Color development, physiochemical properties, and microbiological safety of pork jerky processed with atmospheric pressure plasma. Innov Food Sci Emerg Technol 53:78-84.

Yong HI, Park J, Kim HJ, Jung S, Park S, Lee HJ, Choe W, Jo C. 2018. An innovative curing process with plasmatreated water for production of loin ham and for its quality and safety. Plasma Process Polym 15:1700050.

(c) Copyright. Korean Society for Food Science of Animal Resources.

Date Received Jul. 13, 2020 Date Revised Jul. 22, 2020 Date Accepted Jul. 23, 2020 